\title{
Repetitive mild concussion in subjects with a vulnerable cholinergic system: lasting cholinergic-attentional impairments in $\mathrm{CHT}^{+/-}$mice.
}

Ajeesh Koshy Cherian¹, Natalie C. Tronson¹, Vinay Parikh², Aaron Kucinski ${ }^{1}$, Randy D. Blakely ${ }^{3}$, and Martin Sarter ${ }^{*}$

Department of Psychology and Neuroscience Program, University of Michigan, Ann Arbor, MI 48109, USA

${ }^{1}$ Department of Psychology and Neuroscience Program, University of Michigan, Ann Arbor, MI 48109, USA; '2Department of Psychology and Neuroscience Program, Temple University, Philadelphia, PA 19122, USA; ${ }^{3} \mathrm{FAU}$ Brain Institute, Charles E. Schmidt College of Medicine, Florida Atlantic University, Jupiter, FL 33458, USA

Running Title: Brain injury in $\mathrm{CHT}^{+/-}$mice

Number of pages: 25

Number of figures: 5

Number of words: Abstract: 228; Introduction: 639; Discussion: 1,216.

Author Contributions: A.K.C., N.C.T. and M.S. designed research. A.K.C., N.C.T. and V.P. performed research. A.K. analyzed the data. R.D.B. contributed reagents/analytical tools. A.K.C., N.C.T, R.D.B. and M.S. wrote the paper.

Acknowledgements: This research was supported by PHS grant MH086530 (MS) and the Dystonia Medical Research Foundation (RDB). We thank Marc Bradshaw (University of Michigan) for designing, building and estimating the force of the impact device used in this study. A preprint of this paper was posted online on bioRxiv (doi: http://dx.doi.org/10.1101/521484).

Competing Financial Interests: The authors declare no competing financial interest.

${ }^{*}$ Correspondence: Martin Sarter, Department of Psychology and Neuroscience Program, University of Michigan, 530 Church Street, 4030 East Hall, Ann Arbor, MI 48109; email: msarter@umich.edu 


\begin{abstract}
Previous research emphasized the impact of traumatic brain injury on cholinergic systems and associated cognitive functions. Here we addressed the converse question: Because of the available evidence indicating cognitive and neuronal vulnerabilities in humans expressing lowcapacity cholinergic systems or with declining cholinergic systems, do injuries cause more severe cognitive decline in such subjects, and what cholinergic mechanisms contribute to such a vulnerability? Using mice heterozygous for the choline transporter $\left(\mathrm{CHT}^{+/-}\right.$mice $)$as a model for a limited cholinergic capacity, we investigated the cognitive and neuronal consequences of repeated, mild concussion injuries ( $\mathrm{rmCc}$ ). Following five rmCc, and compared with WT mice, $\mathrm{CHT}^{+/-}$mice exhibited severe and lasting impairments in sustained attention performance, consistent with effects of cholinergic losses on attention. However, rmCc did not affect the integrity of neuronal cell bodies and did not alter the density of cortical synapses. As a cellular mechanism potentially responsible for the attentional impairment in $\mathrm{CHT}^{+/-}$mice, we found that rmCc nearly completely attenuated performance-associated, CHT-mediated choline transport. These results predict that subjects with an already vulnerable cholinergic system will experience severe and lasting cognitive-cholinergic effects following even relatively mild injuries. If confirmed in humans, such subjects may be excluded from, or receive special protection against, activities involving injury risk. Moreover, the treatment and long-term outcome of traumatic brain injuries may benefit from determining the status of cholinergic systems and associated cognitive functions.
\end{abstract}

Key words: Acetylcholine, Choline transporter, Concussion, Traumatic brain injury, Attention, 
Basal forebrain (BF) cholinergic projections to telencephalic regions mediate the integration of extero- and interoceptive cues into ongoing behavior and foster experience-based neuroplasticity (Ballinger, Ananth, Talmage, \& Role, 2016; Conner, Chiba, \& Tuszynski, 2005; Sarter, Albin, Kucinski, \& Lustig, 2014). Among the behavioral and cognitive functions which depend on cholinergic activity, attentional performance, including the detection of cues (as defined by Posner, Snyder, \& Davidson, 1980), and the capacity for attentional (or "top-down") control, is closely linked to cholinergic signaling (Berry, Blakely, Sarter, \& Lustig, 2015; Gritton et al., 2016; Howe et al., 2013; Howe et al., 2017; Kim, Muller, Bohnen, Sarter, \& Lustig, 2017a; Parikh, Kozak, Martinez, \& Sarter, 2007; Sarter, Lustig, Berry, et al., 2016; Sarter, Lustig, Blakely, \& Koshy Cherian, 2016; Sarter, Lustig, Howe, Gritton, \& Berry, 2014; Sarter \& Paolone, 2011; St Peters, Demeter, Lustig, Bruno, \& Sarter, 2011). As would be expected from such fundamental roles of cholinergic systems, cholinergic losses initiate and exacerbate cognitive-behavioral decline in patients with neurodegenerative disorders (Bohnen et al., 2003; Bohnen et al., 2009; Hampel et al., 2018; Kim et al., 2017a; Kim, Muller, Bohnen, Sarter, \& Lustig, 2017b; Sarter, Albin, et al., 2014).

The exquisite vulnerability of cholinergic neurons to the long-term effects of traumatic brain injury has been extensively documented (e.g., Conner et al., 2005; Dixon, Bao, Long, \& Hayes, 1996; Dixon, Hamm, Taft, \& Hayes, 1994; Dixon et al., 1995; Salmond, Chatfield, Menon, Pickard, \& Sahakian, 2005). Here we addressed the converse question: What are the cholinergic-attentional consequences of brain injury in subjects with an already vulnerable cholinergic system? This question arose in part from our research on human subjects expressing a low-capacity choline transporter (CHT) who exhibit attentional and affective vulnerabilities (Berry et al., 2015; Berry et al., 2014; English et al., 2009; Hahn et al., 2008; Sarter, Lustig, Blakely, et al., 2016), and on patients with Parkinson's disease who, in addition to basal ganglia dopamine losses, exhibit cholinergic losses and attentional impairments which are correlated with their propensity for falls (Kim et al., 2017a, 2017b; Sarter, Albin, et al., 2014). Given these cholinergic-attentional risk factors, are these subjects also at a greater risk for developing severe impairments following traumatic brain injury?

We addressed this question by examining the attentional and cholinergic consequences of repeated mild injuries in mice heterozygous for the $\mathrm{CHT}\left(\mathrm{CHT}^{+/-}\right.$mice). Compared to wild type (WT) mice, $\mathrm{CHT}^{+-}$mice model a cholinergic system that functions at WT levels at baseline but exhibits a limited capacity for sustaining elevated levels of cholinergic neurotransmission, such as during the performance of a Sustained Attention Task (SAT; Ferguson et al., 2004; Paolone, 
Angelakos, Meyer, Robinson, \& Sarter, 2013; Parikh, St. Peters, Blakely, \& Sarter, 2013). However, in the absence of additional challenges on performance or cholinergic neurotransmission, residual ACh release is sufficient to support basic SAT performance in these mice, similar to preserved performance but vulnerability to distractors in humans expressing a low-capacity $\mathrm{CHT}$ variant. Thus, $\mathrm{CHT}^{+/}$mice serve as a useful model to study interactions with an expectedly detrimental manipulation of cholinergic function.

The literature on the effects of traumatic brain injury is complex, in part because seemingly subtle variations in the apparatus and methods used to administer injuries generate substantial differences in primary and secondary injuries (Jassam, Izzy, Whalen, McGavern, \& El Khoury, 2017; Xiong, Mahmood, \& Chopp, 2013). As has been widely discussed, repeated mild concussion injuries (rmCc) are common brain injuries (e.g., Collins et al., 1999; Corrigan, Selassie, \& Orman, 2010). Therefore, we investigated the relative vulnerability of $\mathrm{CHT}^{+/-}$mice to rmCc. We used a modified version of the impact apparatus and method described by Kane et al. (2012; see Methods for details) to administer repeated yet relatively even milder concussion injuries. rmCC produced lasting attentional impairments in $\mathrm{CHT}^{+/-}$mice which were associated with a near complete silencing of $\mathrm{CHT}$ function.

\section{Materials and Methods}

\section{Subjects and housing conditions}

Male and female mice ( $N=76$; see Results for the number of mice per genotype, sex and experimental condition), heterozygous for the choline high-affinity transporter $\left(\mathrm{CHT}^{+/-}\right)$were originally obtained from Vanderbilt University (Ferguson et al., 2004), maintained on a C57BL/6 genetic background for over seven generations and continued to be bred on this background at the University of Michigan. Mice were at least 12 weeks of age and weighed $20-30 \mathrm{~g}$ at the beginning experiments.

Mice were genotyped by a commercial vendor (Transnetyx, Cordova, TN). $\mathrm{CHT}^{+/-}(\mathrm{n}=42)$ and wild type mice $(\mathrm{WT} ; \mathrm{n}=40)$ were housed individually in a temperature $\left(23^{\circ} \mathrm{C}\right)$ and humidity-controlled (45\%) environment, and kept on a 12:12 light/dark cycle (lights on at 7:30 a.m.). Training and testing on the Sustained Attention task (SAT) took place during the light phase. We previously demonstrated that SAT practice evokes a diurnal activity pattern in rats (Gritton, Kantorowski, Sarter, \& Lee, 2012; Gritton, Sutton, Martinez, Sarter, \& Lee, 2009; Paolone, Lee, \& Sarter, 2012), suggesting that mice likewise practiced the SAT during their active period. Mice not performing the SAT had ad libitum access to food and water. SAT-performing mice were gradually waterdeprived over a five-day period prior to the onset of training. Water was then restricted to a 4-min 
period following each training session. During SAT sessions, correct responses were rewarded using sweetened water $(0.2 \%$ saccharin; $6 \mu \mathrm{L}$ per reward; total average session delivery: 0.45 $\mathrm{mL})$. On days without SAT practice, water access in the animals' home cages was increased to 10 min. Food (Rodent Chow, Harlan Teklad, Madison, WI) was available ad libitum. During SAT training, animals' body weights remained stable at $90-100 \%$ of their ad libitum body weights (weighed twice weekly). SAT performing mice were trained 5-6 days per week. All procedures were conducted in adherence with protocols approved by the University of Michigan Institutional Laboratory Animal Care and Use Committee (ILACUC\} and conducted in laboratories accredited by the Association for Assessment and Accreditation of Laboratory Animal Care (AAALAC).

\section{SAT apparatus, task acquisition, and performance measures}

Behavioral training and testing took place using twelve modified operant chambers $(24.10 \mathrm{~cm} \mathrm{~L}$ × $20.00 \mathrm{~cm} \mathrm{~W} \mathrm{\times} 29.50 \mathrm{~cm} \mathrm{H}$; MedAssociates, Inc., St. Albans, VT), situated inside soundattenuated chambers fabricated at the University of Michigan. Each operant chamber contained an intelligence panel equipped with two panel lights $(2.8 \mathrm{~W})$, two retractable "Michigan Controlled Access Response Ports" (MICARPs; St Peters, Cherian, Bradshaw, \& Sarter, 2011), and a liquid dispenser ( $6 \mu \mathrm{L}$ of $0.2 \%$ saccharin in de-ionized water per delivery; Fig. 1a). Stimuli and response recordings were implemented using SmartCtrl Package 8-In/16-Out with additional interfacing by MED-PC for Windows (Med Associates, Inc., St. Albans, VT) and custom programming. The MICARPs were located laterally on either side of the liquid dispenser, and the two panel lights were located directly above the liquid dispenser. The MICARPs and the liquid dispenser each contained perpendicular infrared photo-beams to detect nose-poke responses. A house light (2.8 $\mathrm{W}$ ) was located at the top of the rear wall. Each sound-attenuating chamber was also equipped with a ventilation fan, a video camera, and 4 red LEDs (JameCo P/N 333489; Jameco Valuepro, Belmont, CA).

The task, training procedures, and validity of the SAT performance measures in terms of indicating sustained attention in humans, rats, and mice were previously described (Demeter, Sarter, \& Lustig, 2008; Paolone, Mallory, et al., 2013; St Peters, Cherian, et al., 2011). Briefly, animals were initially shaped to reach the water dispenser using a modified fixed ratio-1 (FR-1) reward schedule. After obtaining $\geq 100$ water rewards within the 40-min training session for two consecutive days, animals began SAT training. First, mice were familiarized with moving MICARPS. Both MICARPS extended until a nose-poke triggered retraction. Mice were required to generate 90 rewards/session and retrieve at least $80 \%$ of these rewards within $1.5 \mathrm{~s}$ after the nose poke for two consecutive sessions before moving to the next training stage. During all 
subsequent training stages, mice were required to distinguish between signal (illumination of the central panel light) and non-signal (no illumination) events by responding to the respective MICARP. The house lights of the cage were kept off until the last stage of training, to increase the relative saliency of the signal and facilitate the learning of the task rules. On signal trials, a left nose-poke was reinforced and termed a "hit." On non-signal trials, a right nose-poke was reinforced and termed a "correct rejection" (for an illustration of trial types see Fig. 1a). Half of the animals were trained following the reverse rules. Incorrect responses to signal trials ("misses") and non-signal trials ("false alarms") triggered an inter-trial interval (12 $\pm 3 \mathrm{~s}$ ) but had no further scheduled consequences. An omission was recorded if the animal failed to nose-poke during the lever extension following an event. Signal and non-signal trials were presented in a pseudorandomized order.

In the first training stage, the signal light remained illuminated for $500 \mathrm{~ms}$ on signal trials. MICARPs were extended $1 \mathrm{~s}$ after the signal onset and remained extended for $4 \mathrm{~s}$ or until a nose poke triggered a retraction. During non-signal trials, the MICARPs were likewise extended for $4 \mathrm{~s}$ or until a nose poke was initiated. Incorrect responses were followed with up to three correction trials, during which the previous trial was repeated. If the animal failed to respond correctly to all three correction trials, a forced trial was initiated, during which only the MICARP corresponding to the correct response extended. After reaching stable performance, defined by at least three consecutive days of obtaining $>60 \%$ hits and correct rejections with $<30 \%$ omissions, signal length and time delay before nose-poke extension were reduced ( $1 \mathrm{sec}$ and $0.5 \mathrm{~s}$, respectively). When animals again reached stable performance, multiple signal durations were introduced (500, 50 , or $25 \mathrm{~ms}$ ). The session length was $40 \mathrm{~min}$, allowing for post hoc analysis of performance over five 8-min blocks. Pseudo-randomization was designed to ensure equal numbers of signal and non-signal trials as well as trials with 500,50 or 25 ms signals (approximately 160 trials/session). Forced correction trials were eliminated at this point. After reaching stable performance, animals moved to the final stage training and the actual SAT task. During this stage, the operant chamber house light was illuminated, requiring animals to sustain orientation towards the signal panel. Criterion performance for undergoing $\mathrm{rmCc}$ was defined as an average of $>60 \%$ hits to $500 \mathrm{~ms}$ trials and correct rejections, $<30 \%$ omissions for five consecutive days. Hits, misses, correct rejections, false alarms, and omissions were recorded for each SAT session. The relative number of hits (hits/hits+misses) was calculated for each signal length, as well as the relative number of correct rejections (correct rejections/correct rejections+false alarms). Measures of performance were calculated separately for each of the five, 8-min task blocks. 


\section{rmCc: apparatus and procedure}

The majority of weight drop impactors described in the literature were designed to produce relatively severe injuries, evidenced by macroanatomical lesions (e.g., Marmarou et al., 1994). Other impactors were used to produce relatively milder and more diffuse injuries but associated procedures limited secondary impacts associated with abrupt rotational head movements which often characterize the impacts suffered by athletes or military personnel (e.g., Milman, Rosenberg, Weizman, \& Pick, 2005; Xiong et al., 2013; Zohar et al., 2003). The rmCC apparatus used in the present study was adopted from Kane et al. (2012; see their Figure 1) but modified to produce a relatively even less severe impact. The apparatus used the energy from a falling weight (190 g; drop height: $50 \mathrm{~cm}$ ) to induce a rapid acceleration onto the head of an unrestrained mouse. The rig consisted of a vertical rod supported from above, a sliding platform and, importantly, a transfer ram equipped with a weight transfer ram with an internal compression spring to absorb a portion of the impact force (Fig. 1f). The transfer ram weighted $20 \mathrm{~g}$, the compression spring (Hillman Group, Cincinnati, OH; Item \#540281, \#94 compression spring) had a free length of 6.35 $\mathrm{cm}$ long, $1.35 \mathrm{~cm}$ when fully compressed, $1.42 \mathrm{~cm}$ in outer diameter, and it had a $0.66 \mathrm{~mm}$ wire diameter. The concussion platform consisted of a Plexiglas chamber $(15 \mathrm{~cm}$ length $X 10 \mathrm{~cm}$ width $X 10 \mathrm{~cm}$ height) with a replaceable slit aluminum foil bed at the top and a foam cushion at the base. Because the impact of the weight interacted with a mouse falling though an aluminum foil "hammock" (below), an estimate of the force reduction afforded by the spring inside the transfer ram (which pushed back on the falling weight and thus effectively reduced its weight), assumed a stationary mouse $(25 \mathrm{~g}$ ) and suggested $1.96 \mathrm{~N}$ without and $1.22 \mathrm{~N}$ with the spring (a reduction of $38 \%)$.

For administering an impact mice were lightly anesthetized with isoflurane and placed chest down on the bed of aluminum foil. The vertical rod was adjusted so that the transfer ram rested on the animal's head between the ears. The sliding platform was loaded, raised to a pre-determined height, and was then released. As the sliding platform hit the bottom of the rod, the transfer ram moved rapidly, imparting a rapid acceleration to the head of the animal. Immediately following the impact, the animal fell freely through the slit aluminum foil onto a foam pad, placed $10 \mathrm{~cm}$ below. This arrangement of the apparatus avoided any crushing type of injury as the head of the animal was not restrained, and it ensured a mild concussive injury produced by the high velocity impact and rapid acceleration of the free moving head and body. Thereafter the mice were immediately transferred to their home cage. The total number of impacts (five) that were administered in the present experiment was based on the results described by Kane et al. (2012), indicating that 5 
impacts (over 5 days) did not disrupt vital functions, the integrity of the skull and brain, and motor performance. Furthermore, our pilot studies indicated that administering 5 impacts over 5 weeks, using our modified apparatus, spared the SAT performance of WT mice but impaired the hit rates of $\mathrm{CHT}^{+/}$-mice. Thus, our modified apparatus and administration regimen were designed to yield a robust performance contrast between the genotypes.

\section{Choline uptake assay}

Performance-associated CHT capacity was measured in cortical synaptosomes isolated immediately after the final SAT session ( 7 days after the $5^{\text {th }} \mathrm{rmCc}$; for a schematic timeline see Fig. 1e) and from a subset of mice from all groups ( $N=16 ; 4$ mice per genotype and condition). Mice were decapitated under urethane anesthesia. Synaptosomes were prepared from isolated tissue as described earlier (Parikh et al., 2013). Briefly, right and left frontal cortices were pooled and homogenized in ice-cold $0.32 \mathrm{M}$ sucrose. The homogenate was centrifuged at $1000 \mathrm{Xg}$ for $4 \mathrm{~min}$ at $4^{\circ} \mathrm{C}$ to remove cellular debris. A synaptosomal pellet was obtained by spinning the resultant supernatant at $12,500 \times \mathrm{g}$ for $10 \mathrm{~min}$. Aliquots $(50 \mu \mathrm{L})$ of crude synaptosomes were incubated with $100 \mu \mathrm{L}\left[{ }^{3} \mathrm{H}\right]$-choline $(0.02-6.0 \mu \mathrm{M})$ in Krebs bicarbonate buffer in the presence and absence of $10 \mu \mathrm{M}$ hemicholinium-3 (HC-3) for 5 min at $37^{\circ} \mathrm{C}$. Transport assays were terminated by transferring the tubes to an ice bath followed by rapid filtration using a cell harvester (Brandel Inc., Gaithersburg, MD). Accumulated radioactivity was determined using a liquid scintillation counter. Protein concentration was measured using Pierce BCA protein assay kit (Thermo Fisher scientific Inc., Rockford, IL). CHT- mediated choline uptake was determined as total choline uptake minus the uptake in the presence of hemicholinium-3 and maximum transporter velocity (Vmax) and the affinity for choline $(\mathrm{Km})$ were determined.

\section{Western Blotting}

Non-performing WT and $\mathrm{CHT}+/-$ mice ( $\mathrm{N}=16$; $n=3-5$ per group) underwent a total of five rmCc or sham procedures, following the same timeline for $\mathrm{rmCc}$ delivery as was applied to the SATperforming animals (see Fig. 1e). Seven days after the final impact, mice were decapitated under urethane anesthesia. Brains were removed immediately and frontal cortical tissues were dissected on an ice-cold petri dish. Isolated tissues pooled from both hemispheres were homogenized in ice-cold 0.32M sucrose. The homogenate was centrifuged at $1000 \mathrm{Xg}$ for $4 \mathrm{~min}$ at $4^{\circ} \mathrm{C}$ to remove cellular debris. Supernatants were centrifuged at $12,000 \mathrm{Xg}$ for $15 \mathrm{~min}$ at $4^{\circ} \mathrm{C}$ to obtain the crude synaptosomal pellet. Synaptosomes were resuspended in the lysis buffer containing 100 mM Tris- $\mathrm{HCl}, 50$ mM NaCl, 1 mM EDTA, 1 mM EGTA, 1\% SDS, 1\% Triton X-100 and protease inhibitor cocktail. Protein concentrations were determined by using a modified Lowry 
Protein Assay (Pierce, Rockford, IL). CHT immunoblotting was conducted as described in our previous studies (Apparsundaram, Martinez, Parikh, Kozak, \& Sarter, 2005; Parikh, Apparsundaram, Kozak, Richards, \& Sarter, 2006; Parikh et al., 2013). Briefly, samples for SDSPAGE were prepared in Laemmli buffer by heating at $80^{\circ} \mathrm{C}$ for 20 min prior to loading. Proteins (25 $\mathrm{\mu g} /$ sample) were separated on 4-15\% Tris $\mathrm{HCl}$ polyacrylamide gels and transferred on PVDF membranes. A mouse anti-CHT monoclonal antibody (clone 62-2E8; EMD Millipore, Temecula, CA) was used at 1:1000 dilution for the immunodetection of CHT bands. The blots were exposed to a peroxidase-conjugated anti-mouse secondary antibody and ECL Advance chemiluminescent substrate (GE Healthcare, Piscataway, NJ). The resulting chemilluminescent signal was acquired with a Molecular Imager Chemidoc EQ system (Bio-Rad, Hercules, CA). All membranes were stripped in Restore Plus buffer (Pierce) and re-probed with rabbit anti-synaptophysin antibody (Sigma-Aldrich) to detect synaptophysin that served as a general marker for presynaptic terminal proteins. Densitometric analysis of immunoreactive bands was performed by calculating the integrated pixel densities using NIH ImageJ software. To accommodate for any differences in sample loading across different samples, the density of CHT- and synaptophysin-immunoreactive bands was normalized to the levels of $\beta$-tubulin-immunoreactive bands for each sample analyzed.

\section{Histological analyses}

Following the last five days of SAT practice ( 5 days after the $5^{\text {th }}$ rmCc administration; Fig. $1 \mathrm{e}$ ), the brains from a subgroup of animals were harvested for histological analyses. Animals were given an overdose of sodium pentobarbital and perfused with $0.1 \%$ phosphate buffer solution (PBS) followed by $4 \%$ paraformaldehyde in $0.15 \mathrm{M}$ phosphate buffer and $15 \%$ saturated picric acid, $\mathrm{pH}$ 7.4. Brains were post-fixed for $4 \mathrm{~h}$ and were then rinsed in $0.1 \mathrm{M} \mathrm{PBS}$, followed by storing in $30 \%$ sucrose PBS solution until they sank. Coronal sections $(35 \mu \mathrm{m})$ were sliced using a freezing microtome (CM 2000R; Leica) and stored in antifreeze solution until further processing. For assessing macroanatomical damage and gliosis, Nissl-staining was performed on sections mounted on gelatin coated slides after allowing them to dry completely.

Statistical analyses

SAT performance measures (hits, correct rejections and omissions) were compared between genotypes (WT or $\mathrm{CHT}^{\prime-}$ ) and treatments (sham or $\mathrm{rmCc}$ ) using repeated-measures or one- or two-way ANOVAs. Sex was a factor in all analyses. The analysis of hits also included the withinsubject factor signal duration (500, 50, and $25 \mathrm{~ms}$ ). Following significant main effects, post hoc multiple comparisons were conducted using the least significant difference (LSD) test or Mann-Whitney $U$ Test. Statistical analyses were performed using SPSS for Windows (version 
17.0). The Kruskal Wallis test was used to compare CHT-mediate choline uptake and CHT protein levels between experimental groups. In cases of violation of the sphericity assumption, HuyhnFeldt-corrected $F$ - values, along with uncorrected degrees of freedom, are given. Alpha was set at 0.05 or $0.05 / 3$ when designated. Exact $P$ values are reported as recommended previously (Greenwald, Gonzalez, Harris, \& Guthrie, 1996). Variances are reported and illustrated as standard error of the mean (SEM). Effect sizes for selected effects are reported using Cohen's $d$ (Cohen, 1988).

\section{Results}

rmCc-induced severe and lasting attentional impairments in $\mathrm{CHT}^{+-}$mice

WT ( $n=21,12$ females) and $\mathrm{CHT}^{+/-}$mice ( $n=23,15$ females) were trained in the SAT (Fig. 1a) to performance criterion ( $>60 \%$ hits to 500 ms signals, $>60 \%$ correct rejections, and $<30 \%$ omissions for five consecutive days/sessions). The number of sessions to reach this criterion did not differ between WT and $\mathrm{CHT}^{+/-}$mice $\left(\mathrm{t}(42)=0.80, P=0.43\right.$; WT: $98.57 \pm 12.98$ sessions; $\mathrm{CHT}^{+/-}: 86.74 \pm 7.27$ sessions).

Prior to the administration of rmCc, mice were assigned to the four experimental groups (WT sham (SH): n=6 (3 females); WT rmCc: $\mathrm{n}=15$ (9 females); $\mathrm{CHT}^{+/-} \mathrm{SH}: \mathrm{n}=9$ (6 females); $\mathrm{CHT}^{+/-}$ rmCc: $n=14$ (9 females)). SAT performance data obtained from the last 3 sessions prior to the first $\mathrm{Cc}$ administration confirmed that the relative number of hits varied by signal duration $(F(2,72)=310.27, P<0.0001)$. As was expected based on prior evidence showing that basic SAT performance - in the absence of distractor challenges - does not differ between the genotypes (Paolone, Mallory, et al., 2013), presurgery SAT performance did not differ between the groups (main effect of genotype, (future) rmCc, and 3-way interactions involving the factor sex: all $\mathrm{F}<1.56$, all $P>0.21$; main effect of sex: $F(1,36)=2.64, P=0.11)$. Likewise, there were no effects of genotype, (future) $\mathrm{rmCc}$, or sex and no interactions between these factors on the relative number of correct rejections (all $\mathrm{F}<2.51$, all $P>0.12$; Fig. 1c) and the number of omitted trials (all $\mathrm{F}<0.29$, all $P>0.60$; Fig. 1d). These findings is consistent with results from prior experiments indicating that, in the absence of behavioral or pharmacological challenges of SAT performance or cholinergic neurotransmission, the residual capacity of the cholinergic system of $\mathrm{CHT}^{+/-}$mice is sufficient to support SAT performance (Paolone, Mallory, et al., 2013; Parikh et al., 2013). 
Insert Figure 1 about here

Following SAT acquisition, mice were subjected to $\mathrm{SH}$ or $\mathrm{rmCc}$ using a slightly modified version of the method described by Kane et al. (2012; see their Figure 1 for an illustration of the suspended placement of mice, allowing unrestrained head acceleration upon impact). We modified this device to further minimize the effects of rmCc on the attentional performance of WT mice (see Methods for details). Mice were subjected to a total of five rmCc events over 35 days (see Fig. 1e for an illustration of the timeline). The mice practiced the SAT each day except on days when $\mathrm{Cc}$ was administered.

The analysis on the effects of genotype (WT, $\left.\mathrm{CHT}^{+/-}\right), \mathrm{Cc}(\mathrm{SH}, \mathrm{Cc})$, and $\mathrm{rmCc}$ event number (1-5) was conducted separately for hits to each of the three signal durations (with $\alpha=0.05 / 3$ ). In the analysis of hits to longest signals, this 3-way ANOVA indicated a significant main effect of rmCc $(F(1,36)=13.20, P=0.001)$ that interacted with genotype $(F(1,36)=15.18, P=0.001 ; F i g .2 a, b)$. This result reflected that rmCc decreased hit rates in $\mathrm{CHT}^{+/-}$but not in WT mice (Fig. 2a). After the $5^{\text {th }}$ rmCc event, hits to longest signals remained at pre-Cc levels in WT mice but decreased to about $50 \%$ in $\mathrm{CHT}^{+/-}$mice (Cohen's $d=1.80$; Fig. 2b). The effects of rmCc and genotype on hits to shorter (50 ms and $25 \mathrm{~ms}$ ) signals were not significant (all main effects and interactions: all $F<2.29$, all $\mathrm{P}>0.06$ ), reflecting that hit rates to these signals were already relatively low prior to $\mathrm{Cc}$ administration (see also Fig. 1b).

Independent from genotype, the relative number of correct rejections were significantly decreased by rmCc (main effect of rmCc: $F(1,36)=6.36, P=0.02$ ) ; effects of genotype, sex and interactions: all $\mathrm{F}<2.10$, all $P>0.16$; SH (M, SEM): $76.87 \pm 2.16 \%$; rmCc: $70.32 \pm 1.53 \%$; Fig. 2c). As detailed below, the relatively small decrease in correct rejections did not persist in the long-term, and may have reflected a non-cholinergically mediated decrement in instrumental performance (Burk \& Sarter, 2001). The number of omitted trials was not affected by any factor (all $F<3.45$, all $P>0.07$ ).

Insert Figure 2 about here 
Persistent decrease in hits. As the brains of the mice from this experiment were harvested for neurochemical and histological analyses following the final five days of SAT performance after the $5^{\text {th }} \mathrm{rmCc}$ event, the persistence of the impairments in hits over longer periods following the $5^{\text {th }}$ Cc event was determined in a replication sample ( $n=4$ per genotype). These mice continued practicing the SAT for 28 sessions following the $5^{\text {th }}$ rmCc impact (see timeline in Fig. 1e). Compared WT-rmCc mice, continued daily SAT practice did not restore the rmCc-induced decrease of hit rates in $\mathrm{CHT}^{+/-}$mice $(\mathrm{U}=1, \mathrm{P}=0.04$; Fig. $2 \mathrm{e})$. The relative number of correct rejections (Fig. 2f) and the number of omission (not shown) did not differ between the genotypes during SAT sessions 25-28 (both $P>0.08$ ).

rmCc-induced decrease in CHT capacity

Immediately following completion of the final $\left(5^{\text {th }}\right)$ SAT session following the $5^{\text {th }}$ rmCc impact (Fig. $1 \mathrm{e})$, brains were harvested for neurochemical and histological analysis. Our initial focus on CHT capacity and the integrity of cholinergic terminals (below) was based on two reasons. First, we previously demonstrated that the cholinergic neurons of $\mathrm{CHT}^{+/}$mice cannot support sustained increases in cholinergic neurotransmission (Paolone, Mallory, et al., 2013; Parikh et al., 2013). Because of prior evidence indicating that brain injuries disrupt cholinergic function (Dixon et al., 1996), we hypothesized that rmCc may further reduce $\mathrm{CHT}$ capacity in $\mathrm{CHT}^{+/-}$mice and thereby permanently impair their SAT performance.

CHT capacity was determined in cortical synaptosomal preparations from 4 mice per genotype and condition which were harvested following the final SAT session. Saturation kinetic analysis (Fig. 3a) did not indicate effects of phenotype or rmCc on the affinity of choline to the CHT (median $\mathrm{Km}$ value across all 4 groups: $2.16 \mu \mathrm{M} ; 25^{\text {th }} / 75^{\text {th }}$ percentile: $1.39 / 3.86 \mu \mathrm{M}$; Kruskal Wallis test; $\mathrm{H}(3)=2.74, P=0.43$ ). However, the capacity of the $\mathrm{CHT}$, as indicated by maximal velocity (Vmax), differed significantly among the 4 groups $(H(3)=13.06 P<0.0001$, with rank sums of 58 for WT SH, 30 for WT rmCc, 38 for $\mathrm{CHT}^{+/-} \mathrm{SH}$ and 10 for $\mathrm{CHT}^{+/-}$rmCc; Fig. 3b). Post hoc comparisons between the groups indicated that WT $\mathrm{Cc}$ and both $\mathrm{CHT}^{+/-}$groups had Vmax scores that were lower than those obtained from WT SH mice, that rmCc decreased Vmax scores in both genotypes, and that $\mathrm{CHT}^{+/-}$rmCc mice had lower Vmax scores than WT rmCc mice (all $U=0$, all $P=0.028)$. 
Insert Figure 3 about here

rmCc reduced cortical CHT protein in WT mice but not the density of cholinergic terminals Total $\mathrm{CHT}$ protein levels in the brain of $\mathrm{CHT}^{+-}$mice were expected to be approximately half of the levels measured in WT mice (Ferguson et al., 2004; Parikh et al., 2013). We measured total CHT levels in cortical synaptosomes, obtained from 3-5 mice per genotype and condition, and found a significant difference among the four groups (Kruskal Wallis test; $H(3)=9.11, P=0.01$; Figs. 4a,b). The effects of genotype failed to reach significance $(U=0, P=0.057)$; however, median $\mathrm{CHT}$ values (normalized density) precisely reflected the expected impact of $\mathrm{CHT}$ heterozygosity (36.87 versus 18.54; Fig. 4b). rmCc significantly reduced $\mathrm{CHT}$ protein levels in WT mice $(U=0, P=0.02$; Fig. 4b) but had no further effect on $\mathrm{CHT}$ levels in $\mathrm{CHT}^{+/}$mice $(\mathrm{U}=4, P=0.62)$.

Insert Figure 4 about here

Because rmCc-induced decreased in hits mirror the effects of the removal of basal forebrain cholinergic neurons (e.g., McGaughy, Kaiser, \& Sarter, 1996), we determined whether rmCc decreased the density of cortical terminals. Western blot analysis of the vesicular membrane protein synaptophysin (Tarsa \& Goda, 2002; Thiel, 1993; Walaas, Jahn, \& Greengard, 1988) did not indicate effects of $\mathrm{rmCc}$ or genotype on terminal density $(P=0.52$; Figs. $4 a, \mathrm{c})$. These data reject the possibility that $r m C c$ resulted in the loss of cholinergic terminals and that such loss may explain the loss of rmCc-induced CHT capacity (Fig. 3).

\section{Histological analyses}

Consistent with prior findings using this rmCc method (Kane et al., 2012), inspection of Nisslstained brain sections did not indicate loss of cortical matter or disruption of the integrity of cortex and hippocampus (Fig. 5a-d). Thus, both synaptophysin protein levels and Nissl-stained sections indicated that absence of overt tissue damage resulting from rmCC. 
Insert Figure 5 about here

\section{Discussion}

We hypothesized that $\mathrm{CHT}^{+/-}$mice are relatively more vulnerable than WT mice to the cognitive and neuronal effects of $\mathrm{rmCc}$. The impact of our $\mathrm{rmCc}$ procedure was relatively limited as indicated by the absence of effects on attentional performance of WT mice, the macroanatomical integrity of the brains of all groups, and the density of cortical synapses as indicated by synaptophysin levels. In $\mathrm{CHT}^{+/-}$mice, rmCc lastingly impaired the attentional performance. This effect was associated with and, as will be discussed below, likely mediated by, a nearly complete loss of the capacity of cholinergic synapses to import choline via the $\mathrm{CHT}$.

Cholinergic neurotransmission in $\mathrm{CHT}^{+/-}$mice is unaltered at baseline (Ferguson et al., 2004) but exhibits an attenuated capacity for sustaining elevated levels of activity, such as seen during SAT performance (Paolone, Mallory, et al., 2013). In $\mathrm{CHT}^{+/-}$mice, and in the absence of stimulation of cholinergic neurons, the overall reduction of $\mathrm{CHT}$ protein solely reflects a decrease in intracellular CHT density, with synaptosomal plasma membrane CHT density being preserved at WT level (Ferguson et al., 2004; Ferguson et al., 2003; Parikh et al., 2013). In the absence of stimulation, this situation supports WT levels of CHT-mediated choline transport and ACh release in $\mathrm{CHT}^{+/}$ mice. In contrast, stimulation of cholinergic neurons, such as during SAT performance, reveals the attenuated outward mobilization of intracellular CHTs and thus the attenuated capacity for elevated cholinergic neurotransmission (Ferguson et al., 2003; Parikh et al., 2013).

Cholinergic systems mediate two essential aspects of SAT performance. Fast, phasic or transient cholinergic signaling is necessary for scoring hits (Gritton et al., 2016; Howe et al., 2017; Sarter, Lustig, Berry, et al., 2016) while a slower, neuromodulatory component mediates levels of attentional control, including task representation and maintenance, and performance stabilization and recovery following performance challenges (Kim et al., 2017a; Sarter \& Lustig, 2019; Sarter, Lustig, Blakely, et al., 2016; Sarter, Lustig, \& Taylor, 2012; Sarter \& Paolone, 2011; St Peters, Demeter, et al., 2011). In $\mathrm{CHT}^{+/-}$mice, and in the absence of additional performance or cholinergic challenges, SAT performance remains sufficiently supported by residual levels of cholinergic activity (Paolone, Mallory, et al., 2013; Parikh et al., 2013), likely reflecting that cholinergic neurons remain the capacity for generating phasic ACh release events, and that well-practiced SAT performance only minimally taxes attentional control. Following rmCC, however, CHT 
capacity in $\mathrm{CHT}^{+/-}$mice was nearly completely attenuated and thus likely interfered also with the generation of cholinergic transients. Consistent with our prior demonstration of effects of optogenetic silencing of cholinergic transients on SAT performance (Gritton et al., 2016), rmCcinduced near-silencing of $\mathrm{CHT}$ capacity in $\mathrm{CHT}^{+/-}$mice was associated with a permanent suppression of hit rates in these mice.

rmCc reduced SAT-activated choline uptake in WT mice by about $50 \%$ relative to WT SH rats. In $\mathrm{CHT}^{+/-}$mice, rmCc also reduced choline uptake by about $50 \%$ relative to their sham-treated counterparts. However, this effect in $\mathrm{CHT}^{+/}$mice amounted to an approximately $75 \%$ decrease in CHT capacity relative to sham-treated WT mice and, importantly, in $\mathrm{CHT}^{+/-}$mice, rmCC nearly completely attenuated CHT-mediated choline transport (with residual Vmax scores around 2 $\mathrm{pmol} / \mathrm{mg}$ protein/5 min; Fig. 3b).

For the further interpretation of these findings, it is important to note that choline uptake was measured in mice performing the SAT. As was frequently demonstrated, behavioral performance can alter synaptosomal choline uptake (Decker, Pelleymounter, \& Gallagher, 1988; Messier, Durkin, Mrabet, \& Destrade, 1990). Indeed, in WT rats and mice, SAT performance upregulates cortical choline transport, mediated via an increased rate of translocation of CHTs from intracellular sites to plasma membrane (Apparsundaram et al., 2005; Parikh et al., 2013). In $\mathrm{CHT}^{+/-}$ mice, however, SAT performance did not elevate plasma membrane CHT density (Parikh et al., 2013), and thus SAT performance was unlikely to elevate choline uptake in $\mathrm{CHT}^{+/} \mathrm{SH}$ mice. As rmCc exerted similar degrees of reduction of SAT-associated choline transport when compared with sham-operated controls of the same genotype, it is possible that similar cellular mechanisms mediated the effects of rmCc in both genotypes. These mechanisms remain unknown but neither involved the loss of CHTs nor, as suggested by the unchanged synaptophysin protein levels, loss of cortical synapses in general. While our data do not support a gross change in overall synaptic density, more selective measures of cholinergic terminals independent of acetylcholine homeostasis must be implemented to rule out a frank loss of these elements.

Although the present results did not suggest that rmCc produced a fundamentally different effect in WT versus $\mathrm{CHT}^{+/-}$mice, the absolute net effect in $\mathrm{CHT}^{+/}$mice appears essential for understanding their lasting impairments in SAT performance. As shown before, the residual cholinergic capacity of $\mathrm{CHT}^{+/-}$mice is sufficient to support (unchallenged) SAT performance (Paolone, Mallory, et al., 2013), and the present results confirmed this finding. Moreover, after rmCc, WT likewise remain the capacity for such performance, consistent with SAT-associated choline uptake levels that matched those seen in $\mathrm{CHT}^{+-} \mathrm{SH}$ mice. However, in $\mathrm{CHT}^{+/-}$mice, rmCC 
reduced choline uptake to levels that likely were too low to support residual cholinergic mediation of SAT performance. Together, these findings suggest an additive effect of genotype and rmCC on choline transport which, in $\mathrm{CHT}^{+/-}$mice, yielded a robust and lasting cognitive deficit.

Our ongoing studies have indicated the possibility that the effects of rmCc in $\mathrm{CHT}^{+/-}$mice include lasting increases in the activity of pro-neuroinflammatory brain cytokines (Koshy Cherian, Tronson, Parikh, Blakely, \& Sarter, 2015). If confirmed, these findings would suggest escalating detrimental interactions between a relatively low capacity for cholinergic neurotransmission in $\mathrm{CHT}^{+/-}$mice per se, and an exaggerated neuroinflammatory response to rmCc which may further suppress CHT function (see also Zhu, Blakely, \& Hewlett, 2006),

The main results from this experiment predict that in subjects with a relatively low capacity for sustaining elevated levels of cholinergic neurotransmission, even relatively mild concussions will yield severe and lasting cognitive impairments. Thus, not only is the forebrain cholinergic system exquisitely vulnerable to the effects of brain injury (Dixon et al., 1996; Dixon et al., 1994; Dixon, Ma, \& Marion, 1997; Gorman, Fu, Hovda, Murray, \& Traystman, 1996; Salmond et al., 2005), but a vulnerable cholinergic system represents a major risk factor for developing severe cognitive decline after even mild impacts (see also Conner et al., 2005; Field, Gossen, \& Cunningham, 2012). Our research in humans heterozygous for a low capacity CHT version, present in about $10 \%$ of the population, indicated distinct attentional vulnerabilities, an associated failure to activate right prefrontal regions, and vulnerability for depression (Berry et al., 2015; Berry et al., 2014; English et al., 2009; Hahn et al., 2008; Sarter, Lustig, Blakely, et al., 2016). The present data predict that these subjects are also more vulnerable to the effects of rmCc. Likewise, Parkinsonian fallers, who in addition to dopamine losses also exhibit cholinergic losses (Bohnen et al., 2009), and consequently attentional impairments (Kim et al., 2017a, 2017b), would be predicted to suffer from relatively severe consequences of even very mild concussions, thereby possibly further accelerating the progress of the disease (e.g., Perry et al., 2016). Given the essential role of $\mathrm{CHT}$ capacity for cholinergic neurotransmission, $\mathrm{CHT}^{+/-}$mice appear to be a useful model for future research to study the inflammatory mediators of such cholinergic vulnerabilities and to identify potential therapies for limiting the severe effects of mild impacts in vulnerable humans. 


\section{Figure Legends}

\section{Figure 1}

Illustration of the Sustained Attention Task (SAT) and pre-rmCc performance of WT and $\mathrm{CHT}^{+/}$ mice. $\underline{\text { a: }}$ The SAT consisted of a randomized sequence of signal or cue (illumination of the center panel light; see left photograph) and non-signal (or non-cue) events, followed by extension of the two response ports. Hits and correct rejections, but not misses and false alarms, were rewarded. Note the matching colors of the arrows pointing to the response ports for the four response categories and the arrows in the outcome matrix on the top right, indicating that, in cued trials, hits (red arrows) are rewarded and in non-cued trials, correct rejections were rewarded (dark blue). Conversely, misses (pink arrows) and false alarms (light blue arrows) were not rewarded and triggered an intertrial interval. The photographs depict a cue event (left), followed by a hit ( $2^{\text {nd }}$ from the left, red frame, matching the arrow color), and non-cued trial (third from left) followed by a correct rejection (dark blue frame). $\underline{b-d}$ : Prior to the administration of rmCc, SAT performance did not differ between genotypes and mice assigned to receive either $\mathrm{SH}$ or rmCc (for ANOVAs see Results; WT SH: n=6; WT rmCc: $n=15$; $\mathrm{CHT}^{+/-} \mathrm{SH}: \mathrm{n}=9$; $\mathrm{CHT}^{+/-}$rmCc: $\left.n=14\right)$. Neither the relative number of hits to 500,50 , and $25-\mathrm{ms}$ signals $(\underline{b})$, the relative number of correct rejections

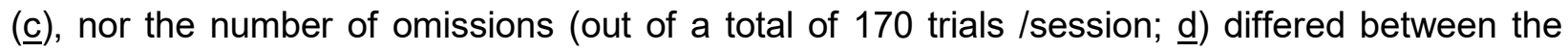
genotypes and assignment to $\mathrm{SH}$ or rmCc. e illustrates the timeline of the main experiment. Following SAT acquisition, five rmCc events were separated individually by 5 days of SAT practice. After the final 5 days of practice, after the $5^{\text {th }}$ event, the brains of the majority of mice were harvested for neurochemical and histological analyses while a small proportion of rmCctreated mice ( $n=4$ per genotype) continued daily SAT practice for an additional 28 sessions to determine lasting effects. $\underline{f}$ shows the transfer ram of the $\mathrm{rmCc}$ apparatus. The addition of this transfer ram constituted the main modification of the apparatus previously used by Kane et al. (2012) to administer repeated, relatively mild impacts in mice. This transfer ram was equipped with an internal compression ring to further limit the impact of the weight drop.

\section{Figure 2}

rmCc decreased hits to longest signals in $\mathrm{CHT}^{+/-}$but not WT mice (a; 6-15 mice per group; note that Fig. 2a does not indicate multiple comparisons because the factor rmCc number (1-5) did not interact significantly with the effects of genotype). Concerning hits to longest signals, a significant interaction between the effects of genotype and rmCc (ANOVA in Results) reflected that, following rmCc, hit rates in $\mathrm{CHT}^{+/-}$mice decreased to about $50 \%$ but remained at control levels in WT mice $\left(\underline{\mathrm{b}} ;{ }^{* * *}, P<0.001\right)$. There were no significant effects on hits to shorter signals, likely due to relatively 
low baseline hit rates to 50 - and $25-\mathrm{ms}$ signals (Fig. 1b). rmCc (main effect) significantly reduced correct rejections by about $7 \%$ in both genotypes (ㄷ). The number of omissions was not significantly affected by genotype or $\mathrm{rm}-\mathrm{TBI}(\underline{\mathrm{d}})$. A small proportion of rmCc-treated mice ( $n=4 /$ genotype) continued practicing the SAT for 28 days following the final impact. Continued SAT practice did not abolish the rmCc-induced decrease in hits in $\mathrm{CHT}+/-$ mice (e); boxes extend from the $25^{\text {th }}$ to 75 percentiles and whiskers show the range of data; medians are also shown). Correct rejections (f) did no longer differ between the genotypes during sessions 25-28.

\section{Figure 3}

Cortical synaptosomal preparations were generated from mice which completed the last SAT practice session after the $5^{\text {th }} \mathrm{rmCc}$ or $\mathrm{SH}$ event ( $\mathrm{n}=4$ per genotype and treatment). Saturation kinetics analysis of hemicholinium (HC-3)-sensitive choline uptake (a) indicated significant group differences in Vmax (므) but not Km (not shown). $\underline{b}$ depicts boxes and whiskers (boxes depict the $25^{\text {th }}$ and 75 percentile, whiskers indicate the lowest and highest value) of Vmax scores. The results from a Kruskal Wallis test indicated a highly significant difference between the groups (see Results) that was followed up by non-parametric multiple comparisons shown here $\left({ }^{*}, P<0.05\right)$. Note that previous studies demonstrated similar basal; (unstimulated) Vmax values in WT and $\mathrm{CHT}^{+/-}$mice. Thus, the relatively lower $\mathrm{Vmax}$ values in $\mathrm{CHT}^{+/-} \mathrm{SH}$ mice, when compared with WT SH mice, reflect SAT performance-induced stimulation of cholinergic activity, thereby revealing the limited outward trafficking of the $\mathrm{CHT}$ in $\mathrm{CHT}^{+/-}$mice (Parikh et al., 2013). rmCc significantly reduced $\mathrm{CHT}$ capacity in $\mathrm{WT}$ and $\mathrm{CHT}^{+/-}$mice, with the latter mice showing significantly lower Vmax values than the other three groups.

\section{Figure 4}

Immunoblot analysis of cortical $\mathrm{CHT}$ and synaptophysin protein levels in WT and $\mathrm{CHT}^{+/-}$mice following SH or rmCc. a Immunoblots showed the expectedly reduced total $\mathrm{CHT}$ levels in $\mathrm{CHT}^{+/}$ mice when compared to levels in WT SH mice (the two bands per group and condition indicate data from two mice each). Furthermore, the rmCc-induced decrease in CHT levels in WT mice is apparent. These examples also indicate that synaptophysin levels did not differ between the phenotypes and $\mathrm{SH}$ versus rmCc. $\underline{b}$ and $\underline{\mathrm{c}}$ depict normalized, integrated $\mathrm{CHT}$ and synaptophysin levels, respectively $\left({ }^{*}, P<0.05\right.$, based on Kruskal Wallis test and multiple non-parametric comparisons; the genotype effect in $\mathrm{SH}$ mice failed to reach significance; $P=0.057$ ).

\section{Figure 5}


Nissl-stained agranular motor and granular somatosensory motor $(a, b)$, and dorsal hippocampus (c,d), of a WT SH and a $\mathrm{CHT}^{+/-}$rmCc mouse (100 $\mu \mathrm{m}$ scale shown in $\left.\underline{\mathrm{a}-\mathrm{d}}\right)$. As was expected from prior studies using a comparable method to generate rmCc (Kane et al., 2012), the relatively milder rmCc method employed in the present experiments did not yield evidence of apparent macroanatomical damage or gliosis in the brains of wild type of $\mathrm{CHT}^{+/-}$mice. 


\section{References}

Apparsundaram, S., Martinez, V., Parikh, V., Kozak, R., \& Sarter, M. (2005). Increased capacity and density of choline transporters situated in synaptic membranes of the right medial prefrontal cortex of attentional task-performing rats. J Neurosci, 25(15), 3851-3856. doi:10.1523/JNEUROSCI.0205-05.2005

Ballinger, E. C., Ananth, M., Talmage, D. A., \& Role, L. W. (2016). Basal Forebrain Cholinergic Circuits and Signaling in Cognition and Cognitive Decline. Neuron, 91(6), 1199-1218. doi:10.1016/j.neuron.2016.09.006

Berry, A. S., Blakely, R. D., Sarter, M., \& Lustig, C. (2015). Cholinergic capacity mediates prefrontal engagement during challenges to attention: evidence from imaging genetics. Neuroimage, 108, 386-395. doi:10.1016/j.neuroimage.2014.12.036

Berry, A. S., Demeter, E., Sabhapathy, S., English, B. A., Blakely, R. D., Sarter, M., \& Lustig, C. (2014). Disposed to distraction: genetic variation in the cholinergic system influences distractibility but not time-on-task effects. J Cogn Neurosci, 26(9), 1981-1991. doi:10.1162/jocn_a_00607

Bohnen, N. I., Kaufer, D. I., Ivanco, L. S., Lopresti, B., Koeppe, R. A., Davis, J. G., . . DeKosky, S. T. (2003). Cortical cholinergic function is more severely affected in Parkinsonian dementia than in Alzheimer disease: an in vivo positron emission tomographic study. Arch Neurol, 60(12), 1745-1748. doi:10.1001/archneur.60.12.1745

Bohnen, N. I., Müller, M. L. T. M., Koeppe, R. A., Studenski, S. A., Kilbourn, M. A., Frey, K. A., \& Albin, R. L. (2009). History of falls in Parkinson disease is associated with reduced cholinergic activity. Neurology, 73(20), 1670-1676. doi:10.1212/WNL.0b013e3181c1ded6

Burk, J. A., \& Sarter, M. (2001). Dissociation between the attentional functions mediated via basal forebrain cholinergic and GABAergic neurons. Neuroscience, 105(4), 899-909.

Cohen, J. (1988). Statistical power analysis for the behavioral sciences (2nd ed.). Hillsdale, N.J.: L. Erlbaum Associates.

Collins, M. W., Grindel, S. H., Lovell, M. R., Dede, D. E., Moser, D. J., Phalin, B. R., . . McKeag, D. B. (1999). Relationship between concussion and neuropsychological performance in college football players. Jama-Journal of the American Medical Association, 282(10), 964970. doi:DOI 10.1001/jama.282.10.964

Conner, J. M., Chiba, A. A., \& Tuszynski, M. H. (2005). The basal forebrain cholinergic system is essential for cortical plasticity and functional recovery following brain injury. Neuron, 46(2), 173-179. doi:10.1016/j.neuron.2005.03.003 
Corrigan, J. D., Selassie, A. W., \& Orman, J. A. (2010). The epidemiology of traumatic brain injury. J Head Trauma Rehabil, 25(2), 72-80. doi:10.1097/HTR.0b013e3181ccc8b4

Decker, M. W., Pelleymounter, M. A., \& Gallagher, M. (1988). Effects of training on a spatial memory task on high affinity choline uptake in hippocampus and cortex in young adult and aged rats. J Neurosci, 8(1), 90-99.

Demeter, E., Sarter, M., \& Lustig, C. (2008). Rats and humans paying attention: cross-species task development for translational research. Neuropsychology, 22(6), 787-799. doi:10.1037/a0013712

Dixon, C. E., Bao, J., Long, D. A., \& Hayes, R. L. (1996). Reduced evoked release of acetylcholine in the rodent hippocampus following traumatic brain injury. Pharmacol Biochem Behav, 53(3), 679-686.

Dixon, C. E., Hamm, R. J., Taft, W. C., \& Hayes, R. L. (1994). Increased anticholinergic sensitivity following closed skull impact and controlled cortical impact traumatic brain injury in the rat. J Neurotrauma, 11(3), 275-287.

Dixon, C. E., Liu, S. J., Jenkins, L. W., Bhattachargee, M., Whitson, J. S., Yang, K., \& Hayes, R. L. (1995). Time course of increased vulnerability of cholinergic neurotransmission following traumatic brain injury in the rat. Behav Brain Res, 70(2), 125-131.

Dixon, C. E., Ma, X., \& Marion, D. W. (1997). Reduced evoked release of acetylcholine in the rodent neocortex following traumatic brain injury. Brain Res, 749(1), 127-130.

English, B. A., Hahn, M. K., Gizer, I. R., Mazei-Robison, M., Steele, A., Kurnik, D. M., . . Blakely, R. D. (2009). Choline transporter gene variation is associated with attention-deficit hyperactivity disorder. J Neurodev Disord, 1(4), 252-263. doi:10.1007/s11689-009-90338

Ferguson, S. M., Bazalakova, M., Savchenko, V., Tapia, J. C., Wright, J., \& Blakely, R. D. (2004). Lethal impairment of cholinergic neurotransmission in hemicholinium-3-sensitive choline transporter knockout mice. Proc Natl Acad Sci USA, 101(23), 8762-8767. doi:10.1073/pnas.0401667101

Ferguson, S. M., Savchenko, V., Apparsundaram, S., Zwick, M., Wright, J., Heilman, C. J., . . . Blakely, R. D. (2003). Vesicular localization and activity-dependent trafficking of presynaptic choline transporters. J Neurosci, 23(30), 9697-9709.

Field, R. H., Gossen, A., \& Cunningham, C. (2012). Prior pathology in the basal forebrain cholinergic system predisposes to inflammation-induced working memory deficits: reconciling inflammatory and cholinergic hypotheses of delirium. J Neurosci, 32(18), 62886294. doi:10.1523/JNEUROSCI.4673-11.2012 
Gorman, L. K., Fu, K., Hovda, D. A., Murray, M., \& Traystman, R. J. (1996). Effects of traumatic brain injury on the cholinergic system in the rat. J Neurotrauma, 13(8), 457-463.

Greenwald, A. G., Gonzalez, R., Harris, R. J., \& Guthrie, D. (1996). Effect sizes and p values: What should be reported and what should be replicated? Psychophysiology, 33(2), 175183.

Gritton, H. J., Howe, W. M., Mallory, C. S., Hetrick, V. L., Berke, J. D., \& Sarter, M. (2016). Cortical cholinergic signaling controls the detection of cues. Proc Natl Acad Sci U S A, 113(8), E1089-1097. doi:10.1073/pnas.1516134113

Gritton, H. J., Kantorowski, A., Sarter, M., \& Lee, T. M. (2012). Bidirectional interactions between circadian entrainment and cognitive performance. Learn Mem, 19(3), 126-141. doi:10.1101/lm.023499.111

Gritton, H. J., Sutton, B. C., Martinez, V., Sarter, M., \& Lee, T. M. (2009). Interactions between cognition and circadian rhythms: attentional demands modify circadian entrainment. Behav Neurosci, 123(5), 937-948. doi:10.1037/a0017128

Hahn, M. K., Blackford, J. U., Haman, K., Mazei-Robison, M., English, B. A., Prasad, H. C., . . . Shelton, R. (2008). Multivariate permutation analysis associates multiple polymorphisms with subphenotypes of major depression. Genes Brain Behav, 7(4), 487-495. doi:10.1111/j.1601-183X.2007.00384.x

Hampel, H., Mesulam, M. M., Cuello, A. C., Farlow, M. R., Giacobini, E., Grossberg, G. T., . . . Cholinergic System Working, G. (2018). The cholinergic system in the pathophysiology and treatment of Alzheimer's disease. Brain. doi:10.1093/brain/awy132

Howe, W. M., Berry, A. S., Francois, J., Gilmour, G., Carp, J. M., Tricklebank, M., . . Sarter, M. (2013). Prefrontal cholinergic mechanisms instigating shifts from monitoring for cues to cue-guided performance: converging electrochemical and $\mathrm{fMRI}$ evidence from rats and humans. J Neurosci, 33(20), 8742-8752. doi:10.1523/JNEUROSCI.5809-12.2013

Howe, W. M., Gritton, H. J., Lusk, N. A., Roberts, E. A., Hetrick, V. L., Berke, J. D., \& Sarter, M. (2017). Acetylcholine release in prefrontal cortex promotes gamma oscillations and thetagamma coupling during cue detection. $J$ Neurosci, 37(12), 3215-3230. doi:10.1523/JNEUROSCI.2737-16.2017

Jassam, Y. N., Izzy, S., Whalen, M., McGavern, D. B., \& El Khoury, J. (2017). Neuroimmunology of Traumatic Brain Injury: Time for a Paradigm Shift. Neuron, 95(6), 1246-1265. doi:10.1016/j.neuron.2017.07.010 
Kane, M. J., Angoa-Perez, M., Briggs, D. I., Viano, D. C., Kreipke, C. W., \& Kuhn, D. M. (2012). A mouse model of human repetitive mild traumatic brain injury. $J$ Neurosci Methods, 203(1), 41-49. doi:10.1016/j.jneumeth.2011.09.003

Kim, K., Muller, M., Bohnen, N. I., Sarter, M., \& Lustig, C. (2017a). The cortical cholinergic system contributes to the top-down control of distraction: Evidence from patients with Parkinson's disease. Neuroimage, in press. doi:10.1016/j.neuroimage.2017.12.012

Kim, K., Muller, M., Bohnen, N. I., Sarter, M., \& Lustig, C. (2017b). Thalamic cholinergic innervation makes a specific bottom-up contribution to signal detection: Evidence from Parkinson's disease patients with defined cholinergic losses. Neuroimage, 149, 295-304. doi:10.1016/j.neuroimage.2017.02.006

Koshy Cherian, A., Tronson, N. C., Parikh, V., Blakely, R. D., \& Sarter, M. (2015). Elevated brain cytokine levels associated with cognitive vulnerability of $\mathrm{CHT}+/-$ mice following repeated mild traumatic brain injury. Society for Neuroscience Annual Meeting, Chicago, IL.

Marmarou, A., Foda, M. A., van den Brink, W., Campbell, J., Kita, H., \& Demetriadou, K. (1994). A new model of diffuse brain injury in rats. Part I: Pathophysiology and biomechanics. $J$ Neurosurg, 80(2), 291-300. doi:10.3171/jns.1994.80.2.0291

McGaughy, J., Kaiser, T., \& Sarter, M. (1996). Behavioral vigilance following infusions of 192 lgGsaporin into the basal forebrain: selectivity of the behavioral impairment and relation to cortical AChE-positive fiber density. Behav Neurosci, 110(2), 247-265.

Messier, C., Durkin, T., Mrabet, O., \& Destrade, C. (1990). Memory-improving action of glucose: indirect evidence for a facilitation of hippocampal acetylcholine synthesis. Behav Brain Res, 39(2), 135-143.

Milman, A., Rosenberg, A., Weizman, R., \& Pick, C. G. (2005). Mild traumatic brain injury induces persistent cognitive deficits and behavioral disturbances in mice. J Neurotrauma, 22(9), 1003-1010. doi:10.1089/neu.2005.22.1003

Paolone, G., Angelakos, C. C., Meyer, P. J., Robinson, T. E., \& Sarter, M. (2013). Cholinergic control over attention in rats prone to attribute incentive salience to reward cues. $J$ Neurosci, 33(19), 8321-8335. doi:10.1523/JNEUROSCI.0709-13.2013

Paolone, G., Lee, T. M., \& Sarter, M. (2012). Time to pay attention: attentional performance timestamped prefrontal cholinergic activation, diurnality, and performance. J Neurosci, 32(35), 12115-12128. doi:10.1523/JNEUROSCI.2271-12.2012

Paolone, G., Mallory, C. S., Koshy Cherian, A., Miller, T. R., Blakely, R. D., \& Sarter, M. (2013). Monitoring cholinergic activity during attentional performance in mice heterozygous for the 
choline transporter: a model of cholinergic capacity limits. Neuropharmacology, 75, 274285. doi:10.1016/j.neuropharm.2013.07.032

Parikh, V., Apparsundaram, S., Kozak, R., Richards, J. B., \& Sarter, M. (2006). Reduced expression and capacity of the striatal high-affinity choline transporter in hyperdopaminergic mice. $\quad$ Neuroscience, 141(1), 379-389. doi:10.1016/j.neuroscience.2006.03.055

Parikh, V., Kozak, R., Martinez, V., \& Sarter, M. (2007). Prefrontal acetylcholine release controls cue detection on multiple timescales. Neuron, 56(1), 141-154. doi:10.1016/j.neuron.2007.08.025

Parikh, V., St. Peters, M., Blakely, R. D., \& Sarter, M. (2013). The presynaptic choline transporter imposes limits on sustained cortical acetylcholine release and attention. J Neurosci, 33(6), 2326-2337. doi:10.1523/JNEUROSCI.4993-12.2013

Perry, D. C., Sturm, V. E., Peterson, M. J., Pieper, C. F., Bullock, T., Boeve, B. F., . . . WelshBohmer, K. A. (2016). Association of traumatic brain injury with subsequent neurological and psychiatric disease: a meta-analysis. $J$ Neurosurg, 124(2), 511-526. doi:10.3171/2015.2.JNS14503

Posner, M. I., Snyder, C. R., \& Davidson, B. J. (1980). Attention and the detection of signals. J Exp Psychol, 109(2), 160-174. doi:10.1523/JNEUROSCI.1833-07.2007

Salmond, C. H., Chatfield, D. A., Menon, D. K., Pickard, J. D., \& Sahakian, B. J. (2005). Cognitive sequelae of head injury: involvement of basal forebrain and associated structures. Brain, 128(Pt 1), 189-200. doi:10.1093/brain/awh352

Sarter, M., Albin, R. L., Kucinski, A., \& Lustig, C. (2014). Where attention falls: Increased risk of falls from the converging impact of cortical cholinergic and midbrain dopamine loss on striatal function. Exp Neurol, 257, 120-129. doi:10.1016/j.expneurol.2014.04.032

Sarter, M., \& Lustig, C. (2019). Cholinergic double duty: cue detection and attentional control. Current Opinion in Psychology, 29, 102-107. doi:10.1016/j.copsyc.2018.12.026

Sarter, M., Lustig, C., Berry, A. S., Gritton, H. J., Howe, W. M., \& Parikh, V. (2016). What do phasic cholinergic signals do? Neurobiology of Learning and Memory, 130, 135-141. doi:10.1016/j.nlm.2016.02.008

Sarter, M., Lustig, C., Blakely, R. D., \& Koshy Cherian, A. (2016). Cholinergic genetics of visual attention: Human and mouse choline transporter capacity variants influence distractibility. J Physiol Paris, 110(1-2), 10-18. doi:10.1016/j.jphysparis.2016.07.001

Sarter, M., Lustig, C., Howe, W. M., Gritton, H. J., \& Berry, A. S. (2014). Deterministic functions of cortical acetylcholine. Eur J Neurosci, 39(11), 1912-1920. doi:10.1111/ejn.12515 
Sarter, M., Lustig, C., \& Taylor, S. F. (2012). Cholinergic contributions to the cognitive symptoms of schizophrenia and the viability of cholinergic treatments. Neuropharmacology, 62(3), 1544-1553. doi:10.1016/j.neuropharm.2010.12.001

Sarter, M., \& Paolone, G. (2011). Deficits in attentional control: cholinergic mechanisms and circuitry-based treatment approaches. Behav Neurosci, 125(6), 825-835. doi:10.1037/a0026227

St Peters, M., Cherian, A. K., Bradshaw, M., \& Sarter, M. (2011). Sustained attention in mice: Expanding the translational utility of the SAT by incorporating the Michigan Controlled Access Response Port (MICARP). Behav Brain Res, 225(2), 574-583. doi:10.1016/j.bbr.2011.08.025

St Peters, M., Demeter, E., Lustig, C., Bruno, J. P., \& Sarter, M. (2011). Enhanced control of attention by stimulating mesolimbic-corticopetal cholinergic circuitry. J Neurosci, 31(26), 9760-9771. doi:10.1523/JNEUROSCI.1902-11.2011

Tarsa, L., \& Goda, Y. (2002). Synaptophysin regulates activity-dependent synapse formation in cultured hippocampal neurons. Proc Natl Acad Sci U S A, 99(2), 1012-1016. doi:10.1073/pnas.022575999

Thiel, G. (1993). Synapsin I, synapsin II, and synaptophysin: marker proteins of synaptic vesicles. Brain Pathol, 3(1), 87-95.

Walaas, S. I., Jahn, R., \& Greengard, P. (1988). Quantitation of nerve terminal populations: synaptic vesicle-associated proteins as markers for synaptic density in the rat neostriatum. Synapse, 2(5), 516-520. doi:10.1002/syn.890020507

Xiong, Y., Mahmood, A., \& Chopp, M. (2013). Animal models of traumatic brain injury. Nat Rev Neurosci, 14(2), 128-142. doi:10.1038/nrn3407

Zhu, C. B., Blakely, R. D., \& Hewlett, W. A. (2006). The proinflammatory cytokines interleukin1 beta and tumor necrosis factor-alpha activate serotonin transporters. Neuropsychopharmacology, 31(10), 2121-2131. doi:10.1038/sj.npp.1301029

Zohar, O., Schreiber, S., Getslev, V., Schwartz, J. P., Mullins, P. G., \& Pick, C. G. (2003). Closedhead minimal traumatic brain injury produces long-term cognitive deficits in mice. Neuroscience, 118(4), 949-955. doi:10.1016/s0306-4522(03)00048-4 
bioRxiv preprint doi: https://doi org/10.1101/521484; this version posted February 5,2019 . The copyright holder for this preprint (which was not certified by peer review) is the author/funder, who has granted bioRxiv a license to display the preprint in perpetuity. It is made available under aCC-BY-NC-ND 4.0 International license.

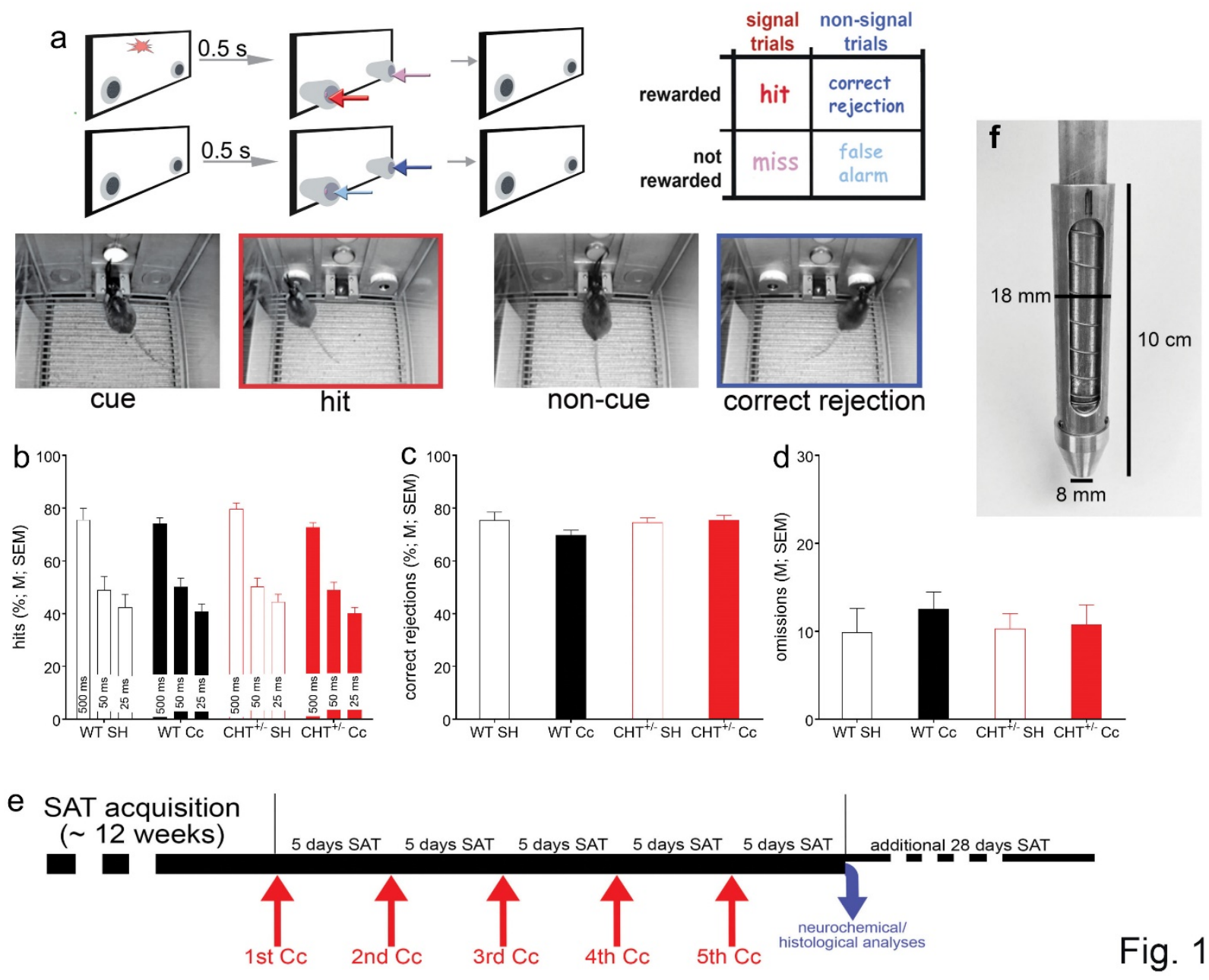


bioRxiv preprint doi: https://doi.org/10.1101/521484; this version posted February 5, 2019. The copyright holder for this preprint (which was not certified by peer review) is the author/funder, who has granted bioRxiv a license to display the preprint in perpetuity. It is made available under aCC-BY-NC-ND 4.0 International license.
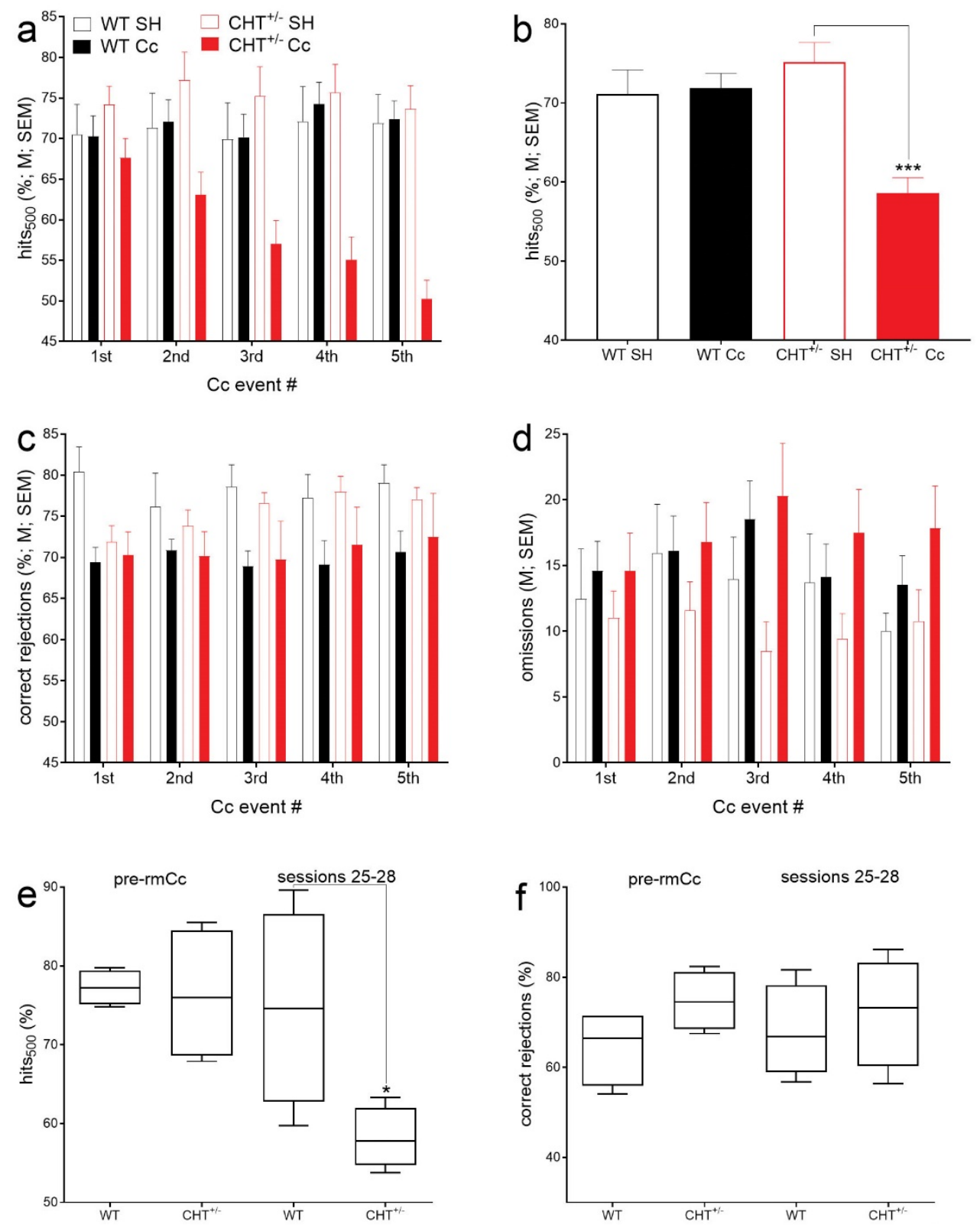

Fiq. 2 
bioRxiv preprint doi: https://doi.org/10.1101/521484; this version posted February 5,2019 . The copyright holder for this preprint (which was not certified by peer review) is the author/funder, who has granted bioRxiv a license to display the preprint in perpetuity. It is made available under aCC-BY-NC-ND 4.0 International license.
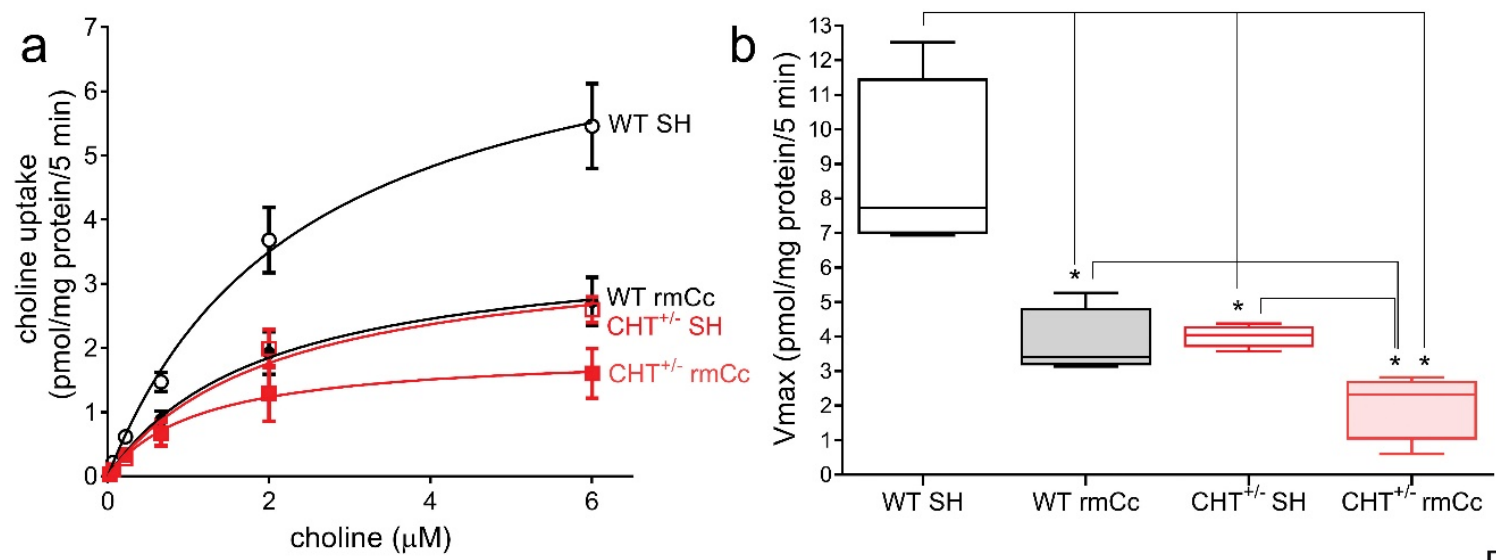

Fig. 3 
a
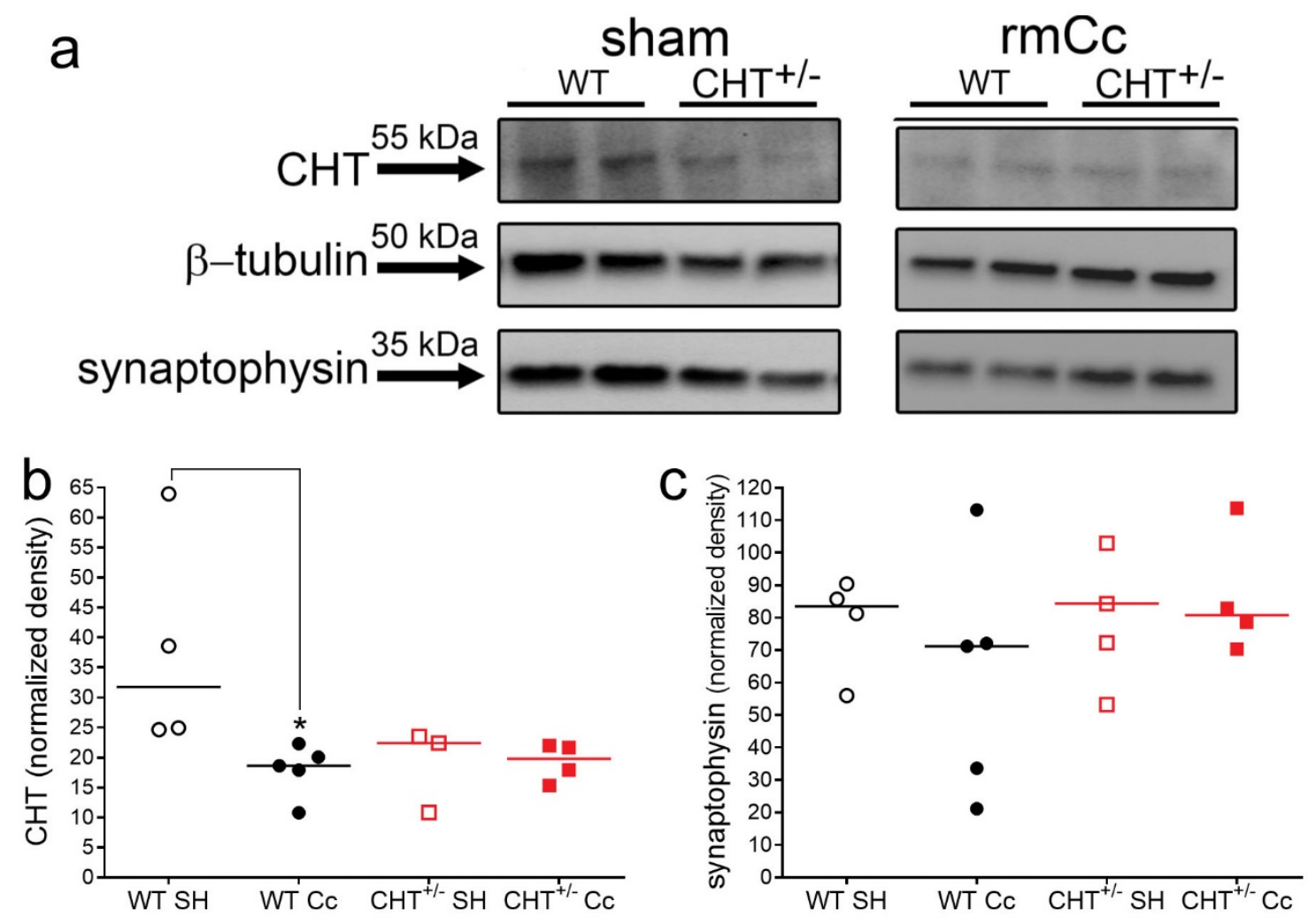

Fig. 4 
bioRxiv preprint doi: https://doi.org/10.1101/521484; this version posted February 5, 2019. The copyright holder for this preprint (which was not certified by peer review) is the author/funder, who has granted bioRxiv a license to display the preprint in perpetuity. It is made available under aCC-BY-NC-ND 4.0 International license.
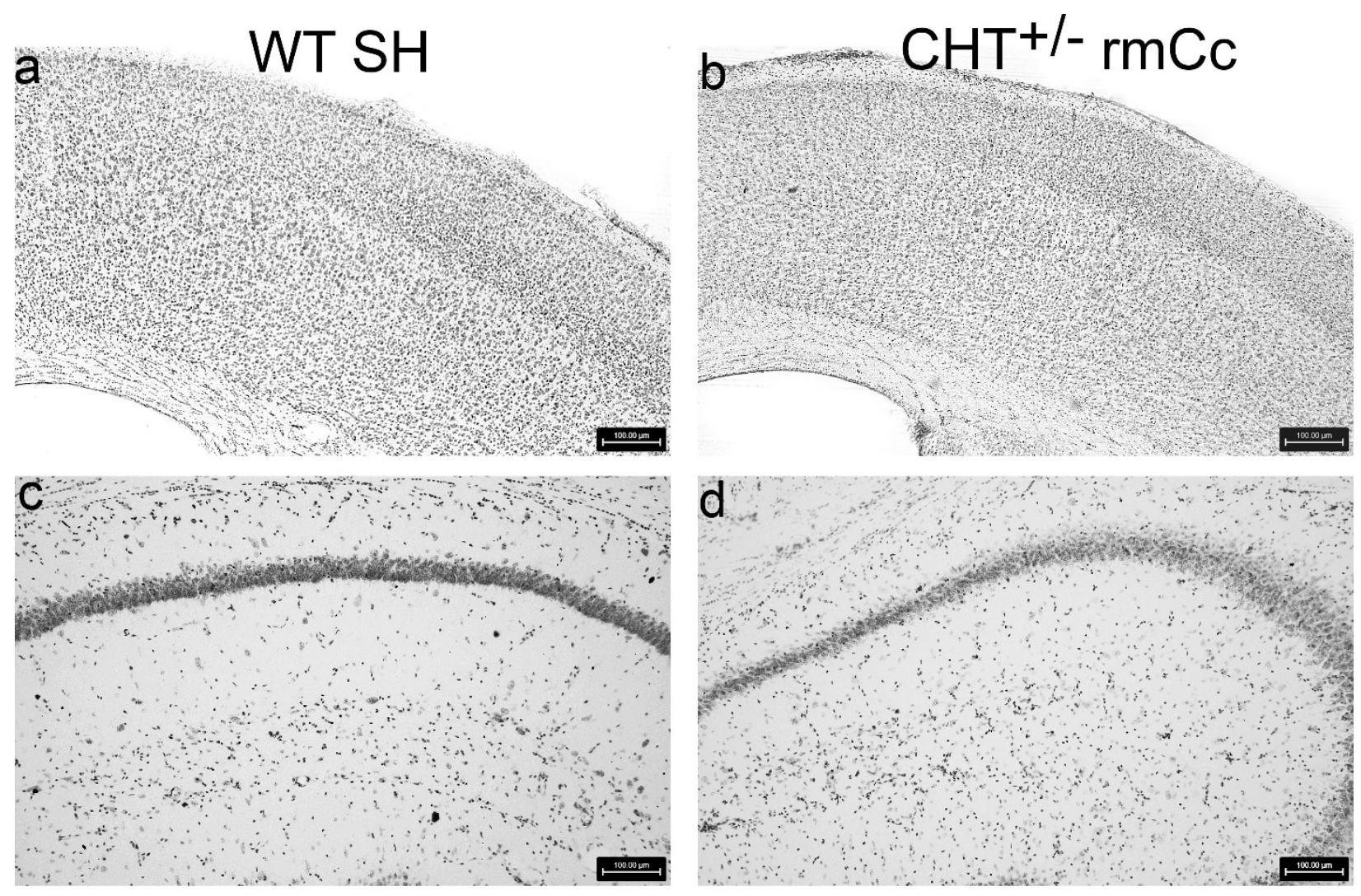

\section{Fig. 5}

